\title{
ЗАСОБИ ТА СПОСОБИ ІМЕНУВАННЯ ЖІНКИ НА ЛЬВІВЩИНІ
}

Наливайко М. Я. Засоби та способи іменування жінки на Львівщині.

У статті проаналізовано імена та інші засоби номінації жінок на Львівщині, а також формули жіночих іменувань. Головним засобом ідентифікації заміжніх жінок $\epsilon$ власні особові імена та андроніми, утворені за допомогою суфіксів від чоловікового імені чи прізвища.

Ключові слова: ім’я, андронім, формула іменування.

Наливайко М. Я. Средства и способы именования женщины на Львовщине.

В статье проанализировано средства именования женщин на Львовщине, а также формулы женских именований. Главним средством идентификации замужних женщин выступают имена собственные и андронимы, образованные с помощью суффиксов от имени или фамилии мужа.

Ключевые слова: имя, адроним, формула именования.

Nalyvajko M. Y. Means and ways of nomination of woman at Lviv region.

The paper analyses women names in Lvivschyna. The main means of identifying married woman were personal names and andronyms, suffixal derivatives of husband's names or surnames.

Key words: personal name, andronym, formula of naming.

Кожна власна назва ідентифікує та індивідуалізує номінований об’єкт у лексичному складі української мови. Створення власного імені (офіційного та неофіційного) є одним із різновидів кодування історично-культурної інформації, у якому відображено об'єктивне та суб'єктивне, мовне і позамовне.

Неофіційні іменування - це додаткові імена, на основі яких ідентифікується та характеризується особа. Вони займають важливе місце в лексичному складі сучасної української мови. Ми дотримуємося погляду, що прізвисько - це неофіційне йменування, яке дають номінатори особі чи колективові людей за індивідуальними ознаками, а також за спорідненістю і свояцтвом між носієм і членами родини для ідентифікації і конкретизації. Прізвиськам притаманні індивідуальність, конотативне забарвлення і вмотивованість.

Прізвиська людей становлять особливий клас пропріальної лексики, оскільки виявляють специфіку на рівні виникнення, функціонування $\mathrm{i}$ взаємозв'язку з екстралінгвальними й інтерлінгвальними чинниками.

Неофіційні іменування монографічно дослідили Н. Павликівська (псевдоніми) [3], П. Чучка (неофіційні іменування Закарпаття) [7], Г. Аркушин (прізвиська північно-західної України) [5], Н. Шульська () М. Я. Наливайко, 2013. 
(неофіційні іменування Західного Полісся) [10].

У пропонованій статті ставимо завдання проаналізувати засоби, та способи, якими ідентифікують жінку на території Львівської області. Українська історична антропонімія - чоловічі іменування грунтовно проаналізовано у праці І. Фаріон [6].

Класифікацію генесіонімних прізвиськ запропонував В. Німчук у «Проекті української ономастичної термінології» [2], виділяючи 4 види: патронім - особова назва сина за іменем батька; матронім особова назва сина за іменем матері; гінеконім - назва чоловіка за іменем дружини; андронім - назва дружини за іменем чоловіка. П. Чучка вказує, що прізвиська цього типу можна б назвати родинними, або родовими, але ці терміни неточно відображають бажаний зміст, тому доцільно називати їх родичівськими, які характеризують іменованого опосередковано - через когось із його родичів або свояків [7, с. 235]. Дослідник зауважує, що для детальної характеристики українських прізвиськ указного типу потрібно 9 термінів: 1) патроніми прізвиська за назвою батька; 2) матроніми - прізвиська за назвою матері; 3) пропатроніми - прізвиська за назвою діда; 4) проматроніми прізвиська за назвою баби; 5) андроніми - прізвиська за назвою чоловіка; 6) гінеконіми - прізвиська за назвою дружини; 7) гіоніми прізвиська за назвою сина; 8) гамброніми - прізвиська за назвою зятя; 9) адельфоніми - прізвиська за назвою брата.

Андроніми. У народнорозмовній системі іменувань для номінації заміжніх жінок не рідше, ніж особове ім'я, використовувалися іменування за чоловіком. Прізвиськами заміжніх жінок жителі Львівщини вважають андроніми, утворені від імені чоловіка, його прізвища, прізвиська або навіть апелятивної особової назви. Іменування за чоловіком П. Чучка зараховує до родичівських прізвиськ [7, с. 299]. Проте на Бойківщині андроніми в абсолютній більшості не вважаються прізвиськами, а в ряді сіл замінюють особові імена заміжніх жінок, ними користуються і при звертанні до жінки $[1$, c. 7]. На Закарпатті андроніми є дуже живучими. Заміжніх жінок у побуті там майже ніколи не називають на їх офіційні прізвища [7, с. 302]. Творення андронімів є живим словотворчим процесом. Так, П. Чучка виділяє понад десять словотвірних типів таких назв у говірках Закарпаття, зокрема назви із суфіксами -их(a), -янк(a), -к(a), $-a \mu^{\prime}(a),-y л^{\prime}(a),-и н(a),-о в(a),-о в к(a),-a,-b \imath н^{\prime}(a)$ [9].

Називання жінки за чоловіком $\epsilon$ найпоширенішим видом іменувань у розмові про третю особу. На території Львівщини здебільшого андронімні типи збігаються із закарпатськими. Нами 
виявлено андроніми, утворені за допомогою таких формантів, як: $-и х(a),-\kappa(a),-о в(a),-y л^{\prime}(a),-a \mu^{\prime}(a),-y \mu^{\prime}(a),-{ }^{\prime} a,-і в \kappa(a),-и ч \kappa(a)$, $-я н к(a), о в к(a),-і в c^{\prime} \kappa(a),-и ш к(a),-и н(a)$.

Серед іменувань жінки за чоловіком значне місце посідають деривати на -ux(a).

Модель із суфіксом -ux(a). Як зазначає П. Чучка, ізоглоса словотвірного типу андронімів на -ux(a) охоплює територію всіх трьох східнослов'янських мов. Джерело продуктивності, на думку вченого, треба шукати у впливі інших формантів, уживаних для означення заміжніх жінок [9, с. 154].

На Львівщині утворення із суфіксом -ux(a) можуть уживатися $\mathrm{i}$ як постійні, стабільні назви, і як разові. Вони здебільшого називають жінок середнього i навіть молодшого віку. Андроніми на -ux(a) сприймаються як стилістично нейтральні і жодного приниження чи образи не виражають [9, с. 154]. Твірну базу андронімів на -ux(a) становлять імена, прізвища, прізвиська, апелятивні означення особи. Проте найчастіше андроніми утворюються від імен чоловіків. У процесі деривації відбуваються різні морфологічні зміни (чергування к-ч, втрата м’якості приголосних).

Андроніми із суфіксом -ux(a), утворені: а) від імені чоловіка: Адамиха, Іваниха, Ільчиха, Матї̈ха, Стефаниха, Яремчиха; б) від прізвища чоловіка: Бараниха, Галендиха, Горбалиха, Доротиха, Жемевчиха, Зварчиха, Купринчиха, Мазуриха, Сливчиха, Солончиха; в) від прізвиська чоловіка: Біленьчиха, Бобриха, Бомчиха, Бузьчиха, Дзюрчиха, Козюриха, Рванулиха, Рибиха, Саранчиха; г) від апелятивної особової назви: Головиха < дружнна голови колгоспу, Ковалиха < коваль, Кравчиха < кравечь, Лісничиха < дружина лісника, Мазуриха < мазур, Пекариха $<$ пекар, Шевчиха < ивець.

Модель із суфіксом -ов(a)/-ев(a). Андроніми із суфіксом -ов(a) функціонують на Закарпатті. Такі андроніми виступають переважно як самостійні субстантивовані номінативні назви [9, с. 158].

У наших матеріалах зафіксовано андроніми на -ов(a), які вживаються переважно $з$ іменем дружини. Це андроніми: а) від імені чоловіка: Андрусьова Леська, Галя Васильова, Гафа Юркова, Касі Трофинова, Параня Стечькова, Прокопова, Симкова; б) від прізвища чоловіка: Бейова, Брикарова Йовка, Вачикова, Дюсуликова, Леся Сайкова, Наді Пастухова, Пичкова, Пікова, Сенютова, Стефка Ліпакова; в) від прізвиська чоловіка: Бицььова, Боброва, Говкова Марина, Кривояцьова, Маланка Балясикова, Мільйонова Стефка, Надя Утьова, Хрушчикова, Цісьова, Цьвочкова; г) від апелятивної 
особової назви: Кравцева Янка - чоловік за фахом кравець, Ксьондзова - чоловік - священик (пор. діал. ксьондз). У ряді сіл Львівщини андроніми на -ов(a) замінюють особові імена заміжніх жінок, ними користуються і при звертанні до жінки.

Модель із суфіксом -к(a). У XVII-XVIII ст. андроніми з суфіксом -к(a) фіксувалися на всіх землях України. Проте валентність суфікса -к(a) була значно нижчою, ніж суфікса -их(a). Він додавався тільки до прізвиськ і патронімів на приголосний [8, с. 614]. В українських говорах Закарпаття найдавніші записи андронімів датуються XVIIXVIII ст. Суфікс -к(a) додається до прізвищ і прізвиськ будь-якої структури [9, с. 153].

На території Львівщини серед іменувань жінки за чоловіком модель із суфіксом -к(a) є досить поширеною. За допомогою цього андронімного форманта утворюються андроніми від імен, прізвищ, прізвиськ та апелятивних характеристик особи.

Андроніми із суфіксом -к(a), утворені: а) від імені чоловіка: Івашка, Толічка, Філіпка Катерина, Франичка; б) від прізвища чоловіка: Бабичка, Лободєчка, Мельничка, Новачка, Смеречка, Цибачка, Шабатурка, Школичка; в) від прізвиська чоловіка: Баранка Оксана, Кобасючка, Котичка, Кочанка, Мазєрка, Хабазничка, Цвандрайка, Чубачка; г) від апелятивної особової назви: Гуиулка < гуиул, Мадярка < мадяр, Шевчичка < шевчик.

У досліджуваному регіоні утворення із формантом -к(a) вживають для називання жінок середнього та старшого віку.

Модель із суфіксом -yл'(a) належить до непродуктивних андронімних моделей. Андроніми із суфіксом -ул'(a) відомі в говорах Закарпаття [9, с. 156], на Бойківщині [1, с. 7].

У наших матеріалах виявлено андроніми з суфіксом -ул'(a), який додається до прізвиськ на кінцевий приголосний: Багачуля < чоловік багач, Дякуля < дяк, Ксьондзуля < ксьондз; до прізвиськ на -ий: Кривуля < Кривий, Рижуля < Рижий, Старуля < Старий, Чорнуля < Чорний. Частина андронімів утворена: а) від імен (Гнатуля < Гнат, Дмитруля < Дмитро, Івануля < Іван, Петруля < Петро) та від прізвищ (Процуля < Проць, Ткачуля < Ткач та ін.).

Модель із суфіксом -'a виявилася непродуктивною на Львівщині. За спостереженням П. Чучки, подібні андроніми лише зрідка функціонують на Закарпатті [9, с. 158]. Нами зафіксовано андроніми від імен Мироня < Мирон, Романя < Роман; від прізвищ Копаничниця < Копаничник, Стасова < Стасів, Тимцева < Тимців; від прізвиськ: Вусаня < Вусань, Когутишина < Когутишин. 
Модель із суфіксом - $a H^{\prime}(a)$. Андроніми із цим формантом $є$ дуже давніми. Він характерний для андронімів Закарпаття [9, с. 155]. На території колишньої Лемківщини ареал андронімів із суфіксом - $a \mu^{\prime}(a)$ охоплює центральну і південно-східну частину [4, с. 38].

Нами зафіксовано андроніми, утворені: від імені чоловіка: Климаня < Клим, Петраня < Петро; від чоловікового прізвиська Дзюбаня < Дзюб та від прізвища чоловіка: Біланя < Білий, Буричканя $<$ Буричка, Чекетаня < Чекета. Зауважимо, що ця модель у досліджуваному регіоні з'явилася під впливом лемківських говірок, тому андроніми на - $a \mu^{\prime}(a) \epsilon$ нехарактерними для території Львівщини.

Модель із суфіксом -ичк(a)/-'aчк(a). У неофіційних іменуваннях Львівщини суфікс -ичк(a) творить андроніми від імені чоловіка: Федунячка < Федір, Франичка < Франко; прізвища чоловіка: Козаричка < Козар, Сливчичка < Сливка, Царичка $<$ Цар, Ширичка $<$ Шира, Шуличка < Шуль; прізвиська: Зозуличка < Зозуля.

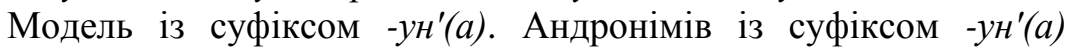
П. Чучка не фіксує на Закарпатті [9, с. 6]. У наших матеріалах трапляються такі андроніми від імені чоловіка: Ігоруня < Ігор, Казюня $<$ Казік < Казимир, Петруня < Петро, Федуня < Федьо < Федір, Юзюня < Юзьо < Йосип; прізвища: Пазька Гербуня < Герба

Модель із суфіксом -івк(a)/-овка. Дослідник закарпатської антропонімії П. Чучка фіксує андроніми із суфіксом -овк(a), утворені від прізвищ, прізвиськ, імен різної структури. Цей словотвірний тип побутує у західних районах Закарпатської області. Перші записи андронімів із суфіксом -овк(a) датують лемківські пам'ятки із середини XVIII ст. [9, с. 157-158].

У неофіційних іменуваннях Львівщини суфікс -івк(a) приєднується до повних та усічених чоловічих імен: Петрівка $<$ Петро, Костівка $<$ Кость, Юзівка < Юзьо; до прізвища: Сасовка $<$ Сас.

Модель із суфіксом -ин(a) творить андроніми від прізвища (Ниччина < Ниць) та прізвиська чоловіка (Ольга Пчілчина < Пчілка, Файчина < Файка).

Модель із суфіксом -'анк(a) належить до непродуктивних. Ми виявили андроніми, утворені від прізвиська чоловіка: Басянка $<$ Бас, Ташолянка < Ташоля. Поодинокими прикладами представлені відпрізвищеві андронімні моделі із суфіксами -івськ(a): Сороківська < Сорока; -ишк(а): Деркачишка < Деркач.

Андроніми функціонують у формі родового відмінка: Марійка Вусатого, Марія Гончого, Надя Довгого, Стефка Дикого, Чорного Юська. 
Отже, на території Львівщини функціонують андронімні моделі

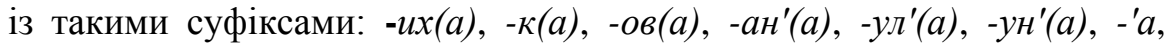
-івк(a), -ичк(a). Найпродуктивнішими виявилися андронімні моделі на $-u x(a),-\kappa(a)$. Активність вживання андронімів серед людей середнього віку свідчить про поширеність неофіційних іменувань жінок. Усього в опрацьованому матеріалі представлено більше 900 андронімів.

Проаналізовані андронімні моделі показують, що вказані форманти приєднуються до різних за походженням твірних основ: церковно-християнських чоловічих імен, прізвищ, прізвиськ, апелятивних характеристик особи (сполучуваності андронімних суфіксів ілюструє таблиця). Найпродуктивнішим є суфікс -ux(a), за допомогою якого утворюються андроніми на території Львівщини. Продуктивними виявилися андроніми 3 формантами -к(a), -ов(a)/-ев(a) для називання заміжніх жінок. Менш поширеними $\epsilon$ андронімні прізвиська 3 формантами -ул'(a), -ан' (a), -ун'(a), -'a, -івк(a), -ичк(a).

\section{Сполучуваність андронімних суфіксів}

\begin{tabular}{|c|c|c|c|c|}
\hline \multirow[b]{2}{*}{ Формант } & \multicolumn{4}{|c|}{ Твірні основи } \\
\hline & Чоловічі імена & Прізвища & Прізвиська & $\begin{array}{c}\text { Апелятивні } \\
\text { характеристики особи }\end{array}$ \\
\hline$-u x(a)$ & 95 & 149 & 129 & 16 \\
\hline$-o b(a) /-e b(a)$ & 84 & 122 & 103 & 14 \\
\hline$-\kappa(a)$ & 12 & 138 & 35 & 14 \\
\hline$-y \pi^{\prime}(a)$ & 6 & 2 & 5 & 3 \\
\hline$-a H^{\prime}(a)$ & 6 & 3 & 1 & - \\
\hline$-' a$ & 2 & 3 & 2 & 1 \\
\hline -ичк(a), -'ачка & 1 & 5 & 1 & - \\
\hline$-y H^{\prime}(a)$ & 5 & 2 & - & - \\
\hline 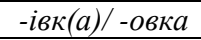 & 4 & 1 & - & - \\
\hline$-и н а$ & - & 1 & 2 & - \\
\hline -'анка & - & - & 2 & - \\
\hline$-и ш к а$ & - & 1 & - & - \\
\hline -івська & - & 1 & - & - \\
\hline
\end{tabular}

Розглянувши андроніми Львівщини, також можемо виділити акцентуаційні варіанти, що побутують на дослідженій території. Андроніми на -их(a) мають суфіксальний наголос: Слисúxa, Kapnúxa, Климчи́ха, Луциихха, Назари́ха, Назарчи́ха, Петруни́ха, Петруси́ха, Пилипи́ха, Пилипчи́ха, Прокопи́ха, Прокопчи́ха, Яни́ха, Янчи́ха, Ячи́ха; або наголос на твірній основі: Ло́гвиниха, Миха́йлиха, Миха́сиха, Петре́йчиха, Поліка́рпиха, Самі́йлиха, Яку́бчиха. У всіх прізвиськах на -к(a) в називному відмінку наголос збігається 3 наголосом 
відповідного твірного чоловічого прізвиська: Козуба́йка < Козуба́й, Ма́занка < Ма́зан, Проца́йка < Проца́й. Андронімам із суфіксами -ан'(a), $-y л^{\prime}(a), \quad-y \mu^{\prime}(a)$ притаманний суфіксальний наголос: Пилипка́ня, Проца́ня, Янка́ня, Яиька́ня; Янку́ля, Яџьки́ля, Казю́ня. В андронімах на -ов(a) / -ев(а) виділяємо наголос на твірній основі: Андру́шкова, Кири́лова; Бо́йкова, Яки́миеева; Ма́кова; суфіксальний наголос: Барано́ва, Бико́ва, Ведмеде́ва, Кріле́ва; Кравце́ва Янка; Паламаро́ва. У непродуктивних андронімних моделях на -'a, -івк(a) наголос падає на твірну основу: Рома́ня; Ко́стівка, Ю́зівка та на суфікс: Петрі́вка.

Патроніми. Термін «патронім» найдоцільніше вживати у значенні «дериват від назви батька». Однак, як зауважує П. Чучка, можна використовувати його у ширшому значенні - «найменування особи, одержане нею по лінії батьків». Дослідник виділяє патроніми експліцитні (патронімні деривати) та патроніми імпліцитні (семантичні утворення). Серед експліцитних патронімів наявні патроніми живі, тобто актуальні, та патроніми неактуальні. Більшість слов'янських патронімів належить до експліцитних утворень. Слов'янським мовам відомо понад 50 патронімних формантів. В імпліцитних патронімах відсутні показники патронімності [8, с. 51-52]. Патронімами представлені одночленні іменування гуцулів XV-XVI ст. [3]. У кінці XVIII - поч. XIX ст. іменування особи за батьком, матір'ю, іншими родичами - найпродуктивніші у двокомпонентному способі називання особи на території Прикарпатської Львівщини [20, с. 24].

На Львівщині патроніми утворюються від імені, прізвища, прізвиська батька, його апелятивної характеристики.

А. Патроніми від імені батька: Бартоньова Славка $<$ Батронь $<$ Бартоломій, Захаркова Мариська < Захарко < Захар, Костьова Галя < Кость < Костянтин, Маринка Назарова < Назар, Михальова Галька < Михальо < Михайло, Нюнькова В'єра < Нюнько < Іван, Олюськова Гєнка < Олюсько < Олександр, Ониськова Манька < Онисько < Онисим. Патроніми, утворені від імені батька, становлять значну кількість (усього понад 320 прізвиськ). Серед іменувань цього типу переважають похідні від демінутивних варіантів імен різної структури. У тому разі, коли імена батьків однотипні, для прізвиська використовуються фонетично урізноманітнені словотвірні варіанти. Так, від імені Іван утворені такі прізвиська: Іванкова Дорка, Нюнькова В 'єра.

Б. Патроніми від прізвища батька: Вольга Бойцунова < Бойцун, Ганя Івана Білого < Білий, Демчукова Ліда < Демчук, Сва Ішукова < Іщук, Манька Мирона Щудлюка < Щудлюк, Ситникова Юлька < Ситник. Більшість їх має посесивну форму. 
В. Патроніми від прізвиська батька: Криштальова Віра < Кришталь, Текля Довганьова < Довгань.

Г. Патроніми від апелятивного означення особи: Ганька Ксьондзова < ксьондз, Манька Циганова < цииан.

До патронімів зараховуємо іменування від прізвища свекра (Пойтичина невістка) і прізвиська (Князьова невістка). Прізвиська, утворені від імені, прізвища, прізвиська та апелятивної назви батька становлять понад 800 іменувань. Аналіз лексичної бази патронімів Львівщини засвідчує, що патронімність властива таким категоріям, як імена, прізвища, прізвиська, апелятивне означення особи.

Пропатроніми. Перенесення імені діда на внука чи внучку найчастіше буває у випадках, коли найменований своїми прикметами (зовнішніми чи внутрішніми) нагадує діда; коли внук чи внучка росли біля діда.

У наших матеріалах виділяємо пропатроніми, утворені від імені, прізвища, прізвиська діда і прадіда, його апелятивного означення:

А. Пропатроніми, утворені від імені діда і прадіда: Антоськова Стефа < Антосько < Антон, Антошкова Маруська $<$ Антошко < Антон, Віркова Люба < Вірко < Вірослав, Петрунькова Оля < Петрунько < Петро, Сенькова Віра < Сенько < Семен, Стахова Люба $<$ Стах < Свстахій, Федькова Ірка $<$ Федько < Федір, Яськова Маня $<$ Ясько $<$ Яків.

Б. Пропатроніми, утворені від прізвища діда і прадіда (по материній лініі): Гаврилюкова Оля < Гаврилюк, Данчукова Манька < Данчук, Касічинська < Касічинський, Музичкова Люська < Музичка, Найдова Стефка < Найда, Повідайкова Варка < Повідайко, Трачева Стася < Трач, Швайкова Февроня < Швайка. Пропатроніми, утворені від імені, прізвища, прізвиська, апелятивного означення особи охоплюють незначну кількість (понад 1000 прізвиськ).

Матроніми. Як зазначає дослідник закарпатської антропонімії П. Чучка, матроніми становлять один із розрядів родичівських прізвиськ [7, с. 295]. На Закарпатті діти часто отримують прізвиська за матір'ю, якщо вони росли при матері без батька; якщо мати більш відома в колективі, ніж батько; якщо дитина є позашлюбною; якщо батько є приймаком [7, с. 295]. Перенесення імені матері на дочку чи сина зумовлене подібністю за зовнішніми чи внутрішніми ознаками.

На Львівщині виявлено в основному такі ж причини називання синів та дочок за матір'ю. Матроніми утворюються від імені, прізвища, прізвиська, апелятивного означення особи.

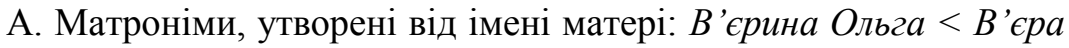


$<$ Віра, Воринчина Маруська < Воринка < Орина, Ксеньчина Оля < Ксенька < Оксана, Маньчина Ганя < Манька < Марія, Мінодора < Мінодора, Мотрунчина Галя < Мотрунка < Мотрона, Ромина Кася < Романія, Химка < Юхима, Циліна <Циліна, Цяня < Сяня < Оксана.

Прізвиська цієї підгрупи зазвичай утворені від квалітативних варіантів імен, лише зрідка від повних імен матерів. Трапляються матроніми, похідні від фонетичних варіантів жіночих імен Ольга, Орина (напр., Воринчина, у яких простежується протетичний звук в).

Б. Матроніми, утворені від дівочого прізвища матері: Гунька (пор. Гунька Стефанія), Жучка (пор. Жук Марія), Левусь Надька (пор. Левусь Марія), Петринка Аля (пор. Петринка Емілія), Стоцька Каська (пор. Стоцька Наталія). Їх небагато, очевидно, традиція іменування за прізвищем матері не набула поширення.

В. Матроніми, утворені від прізвиська матері: Гулька, Перколабишина Маринка < Перколабиха. Прізвиська цієї підгрупи не відзначаються активністю. Їх усього понад 20.

Г. Матроніми, утворені від апелятивного означення особи: Іванка Гоцулчина < гуцулка. Подібних прізвиськ більше нами не зафіксовано. Група прізвиськ, утворених за назвою матері, становить більше 300 назв.

Проматроніми. Дослідники стверджують, що в українських говорах Закарпаття проматроніми виникають за таких умов: а) якщо вихованням дитини займається баба; б) якщо дитина зовнішніми чи внутрішніми рисами схожа на бабу [7, с. 299].

На території Львівщини іменування за іменем, прізвищем, прізвиськом баби належать до непопулярних.

А. Проматроніми за іменем баби: Вольжина Люба $<$ Вольга $<$ Ольга, Дзюнька < Влодзя < Володимира, Маришка < Марія, Таџька $<$ Тацяя Тетяна. Проматроніми цієї підгрупи засвідчують розмовнопобутові варіанти жіночих імен (Дзюнька, Тацька).

Б. Проматроніми за прізвищем баби: Михайлищької Маньки Юлька < Михайлицька. Їх небагато (лише 6). Усі вони мають тричленну структуру. По суті це $є$ утворення від прізвища та імені баби. До проматронімів відносимо назви від імені прабаби (Варвара, Кароліна, Маланя, Рузя Маланчина), прізвиська (Галагурка, Ксьондзишина Стефка). Усього 247 прізвиськ.

Гіоніми - прізвиська, що називають батьків за іменем сина. П. Чучка зауважує, що син мусить відзначитися, щоб під впливом його вчинку називати батька чи матір [7, с. 304]. Із прізвиськ, які називали би батька чи матір, ми зафіксували такі утворення: син Мішко - мати 
Мішкова Юлька, син Штефан-мати Штефанка Зося.

Гамброніми - рідкісний спосіб іменування за зятем [7, с. 305]. На Львівщині такий тип іменування репрезентується відпрізвищевим прізвиськом: зять Скишляк Ігор - теща Скислячка Ірка.

Адельфоніми - іменування за братом [7, с. 305]. Як і два попередні іменування, адельфоніми побутують рідко. Так, наприклад, від імені Руслан утворено іменування сестри Русланкова Таці, від прізвиська Вовк - іменування сестри Вовчиця (усього 10 іменувань).

Отже, компонентами родичівських прізвиськ жінок можуть стати: ім'я батька (Михальова Галька < Михальо < Михайло), матері (Оля Вірчина <Вірка < Віра), діда (Стахова Люба < Свстахій), чоловіка (Мойсейка < Мойсей); прізвище батька (Сва Іщукова < Іщук), діда по материній лінії (Касічинська < Касічинський), чоловіка (Пастушиха < Пастушок); прізвисько батька (Текля Довганьова < Довгань), матері (Перколабишина Маринка < Перколабиха), діда (Горобчева $<$ Горобець), чоловіка (Перчикова $<$ Перчик).

Виділяємо такі шляхи формування родичівських прізвиськ у сучасному мовленні жителів сіл Львівщини: а) пряме перенесення власної назви (імені) з одного родича на іншого, без змін у їі структурі: маму звати Машка, тому дочку Галю теж називають Машка; маму звати Малда, і дочку Марію називають Малда; б) вживання антропонімних словосполучень у родовому відмінку, наприклад, бабу називають Михайлицька, а внучку - Михайлицької Маньки Юлька.

Підсумовуючи, відзначимо, що неофіційна номінація жінки має послідовний характер. В іменуванні жінок часто відсутнє особове ім'я. Функцію його виконує андронім, патронім, матронім, пропатронім, проматронім, гіонім, адельфонім, гамбронім. Отже, іменування жінки формувалося на основі іменування чоловіка - представника родини.

\section{Література}

1. Бучко Г. Є. Народно-побутова антропонімія Бойківщини / Г. Є. Бучко, Д. Г. Бучко // Linguistica slavica : Ювілейний збірник на пошану I. М. Желєзняк. - К. : Кий, 2002. - С. 3-14.

2. Німчук В. В. Українська ономастична термінологія (Проект) / В. В. Німчук // Повідомлення української ономастичної комісії. - Вип. І. - К. : Наукова думка, 1966. C. 24-43.

3. Павликівська Н. М. Питання української псевдонімії XX століття / Н. М. Павликівська. - Вінниця : Глобус-прес, 2011. - 386 с.

4. Панцьо С. Є. Антропонімія Лемківщини / С. Є. Панцьо. - Тернопіль : Книжково-журнальне в-во «Тернопіль», 1995. - 128 с.

5. Словник прізвиськ північно-західної України : у 3-х т. / упор. Г. Л. Аркушин. Луцьк : РВВ «Вежа» Волин. нац. ун-ту ім. Лесі Українки, 2009. 
6. Фаріон I. Д. Українські прізвищеві назви Прикарпатської Львівщини наприкінці XVIII - початку XIX століття (з етимологічним словником) / I. Д. Фаріон. - Львів : Літопис, 2001. $-371 \mathrm{c.}$

7. Чучка П. П. Антропонімія Закарпаття: дис. ... д-ра філол. наук : 10.661 «ови народів СРСР (українська мова)» / П. П. Чучка. - Ужгород, 1969. - 987 с.

8. Чучка П. П. Розвиток імен і прізвищ / П. П. Чучка // Історія української мови (Лексика і фразеологія). - К. : Наук. думка, 1983. - С. 592-620.

9. Чучка П. П. Словотвір українських андронімів / П. П. Чучка // Питання словотвору. - К., 1979. - С. 152-161.

10. Шульська Н. Словник прізвиськ жителів межиріччя Стиру та Горині / Н. Шульська. - Луцьк : Волинська обласна друкарня, 2008. - 164 с.

Стаття надійшла до редакції 22.10.2013 р. 